\title{
小肝細胞癌における高感度 PIVKA-IIの意義
}

\section{一特に進展度，予後との関係について一}

\begin{tabular}{|c|c|c|c|c|c|c|}
\hline 鎌田 & 耕治 & 北本 & 幹也 & 相方 & 浩 & 川上 \\
\hline 高橋 & 祥一 & 大石 & 和佳 & 松本 & 明子 & 重見 \\
\hline 衣 & 英樹 & 石原 & 浩人 & 大畠 & 俊之 & 中西 \\
\hline 本 & 敏行 & 浅原 & 利正 ${ }^{2)}$ & 嶋本 & 文雄 ${ }^{3)}$ & 梶山 \\
\hline
\end{tabular}

\begin{abstract}
要 旨：腫瘍径 $3 \mathrm{~cm}$ 以下の小肝細胞癌82症例 (針生検例 44 例，外科的切除例 38 例) に対し高感 度 PIVKA-II 測定の意義について検討した。PIVKA-II陽性率は腫瘍径 $3.0 \mathrm{~cm}$ 以下で $34 \% ， 2.0$ $\mathrm{cm}$ 以下で $21 \%$ あ゙あっ．組織型別にみると中・低分化型がそれぞれ $52 \% ， 56 \%$ と比較的高率で あったが，高分化型では $3 \%$ と極めて低かった $(\mathrm{P}<0.05)$ ．また切除例における検討で，組織学 的血管侵襲を有する頻度は，PIVKA-II 陽性群で56\%，陰性群で18\%と PIVKA-II陽性群で有 意に高かった $(\mathrm{P}<0.05)$ ．また無再発生存率は PIVKA-II 陽性群は陰性群に比して有意に低率で あった $(\mathrm{P}<0.05)$. 以上のように小肝細胞癌における PIVKA-IIの検出率には限界があるものの, 悪性度や予後予測に有用性が認められた。
\end{abstract}

索引用語： 小肝細胞癌＼cjkstart高感度 PIVKA-II＼cjkstart悪性度

\section{緒言}

近年, 腹部 $\mathrm{CT}$ 検査や腹部超音波検査など画像診断 の進歩により細小肝癌の発見頻度が増加している．早 期発見の補助的診断法として腫瘍マーカーがあるが, PIVKA-II の標準測定法では特異性は高いが感度が低 いため，細小肝癌ではその陰性例が増加している 今回我々は $3 \mathrm{~cm}$ 以下の肝細胞癌症例に対して over night 法で高感度測定することにより，その有用性につ いて検討した。

\section{I 。対象と方法}

1989年から1997年までに初回診断した $3 \mathrm{~cm}$ 以下の小 肝細胞癌82例を対象とした。比較のため慢性肝炎22例, 肝硬変34例，健常者10例を含めた。肝細胞癌は全例針 生検または外科的切除により病理組織学的に診断され ている.すべて単発例である. 肝細胞癌患者の内訳は, 男性55例, 女性27例で, 平均年齢は61.9歳 (男性60歳, 女性65歳)であった。

また，平均腫瘍径は $2.0 \pm 0.5 \mathrm{~cm}$ で，腫瘍径別では $2.0 \mathrm{~cm}$ 以下 52 例, $2.1 \sim 3.0 \mathrm{~cm}$ で30例であった. 針生 検例は 44 例, 外科的切除例は38例であり, 分化度別で

${ }^{11}$ 広島大学第 1 内科, ${ }^{21}$ 同第 2 外科, ${ }^{31}$ 同病理部

<受付日1999年 9 月13日 $>$
は高分化型31例, 中分化型42例, 低分化型 9 例であっ た。臨床病期別では，I 期41例，II期34例，III期 7 例 であった。さらに切除例においては組織学的進展所見 の有無, 生存率, 無再発生存率を検討した。

PIVKA-II測定法はエイテストモノP-IIキットを用 いて over night 法で高感度化を可能にし, 測定限界は $0.0165 \mathrm{AU} / \mathrm{m} l$ であった ${ }^{3)}$. また AFP はラテックス近 赤外比濁法にて測定した。なお1995年以前の検体は一 $20^{\circ} \mathrm{C}$ に凍結保存した血清を使用した. Cut off 值を高感 度 PIVKA-II で0.02AU/m $l$ AFP で $100 \mathrm{ng} / \mathrm{m} l$ とし た。

統計学的検定は, $\chi^{2}$ 検定, Fisher's exact probability 法, Mann Whitney U 検定で行った。生存率は Kaplan-Meier 法により生存関数の推定を行い generalized Wilcoxon 検定を行った. $\mathrm{P}<0.05$ 有意差ありと した.

\section{II. 成績}

\section{1. 各種肝疾患における高感度 PIVKA-II測定値}

(Fig.1)

健常者では陽性例を認めなかった。慢性肝炎および 肝硬変もわずかに陽性例を認めたが，その陽性率は各々 $9 \% ， 6 \%$ と低率であった. 肝細胞癌全体の高感度 


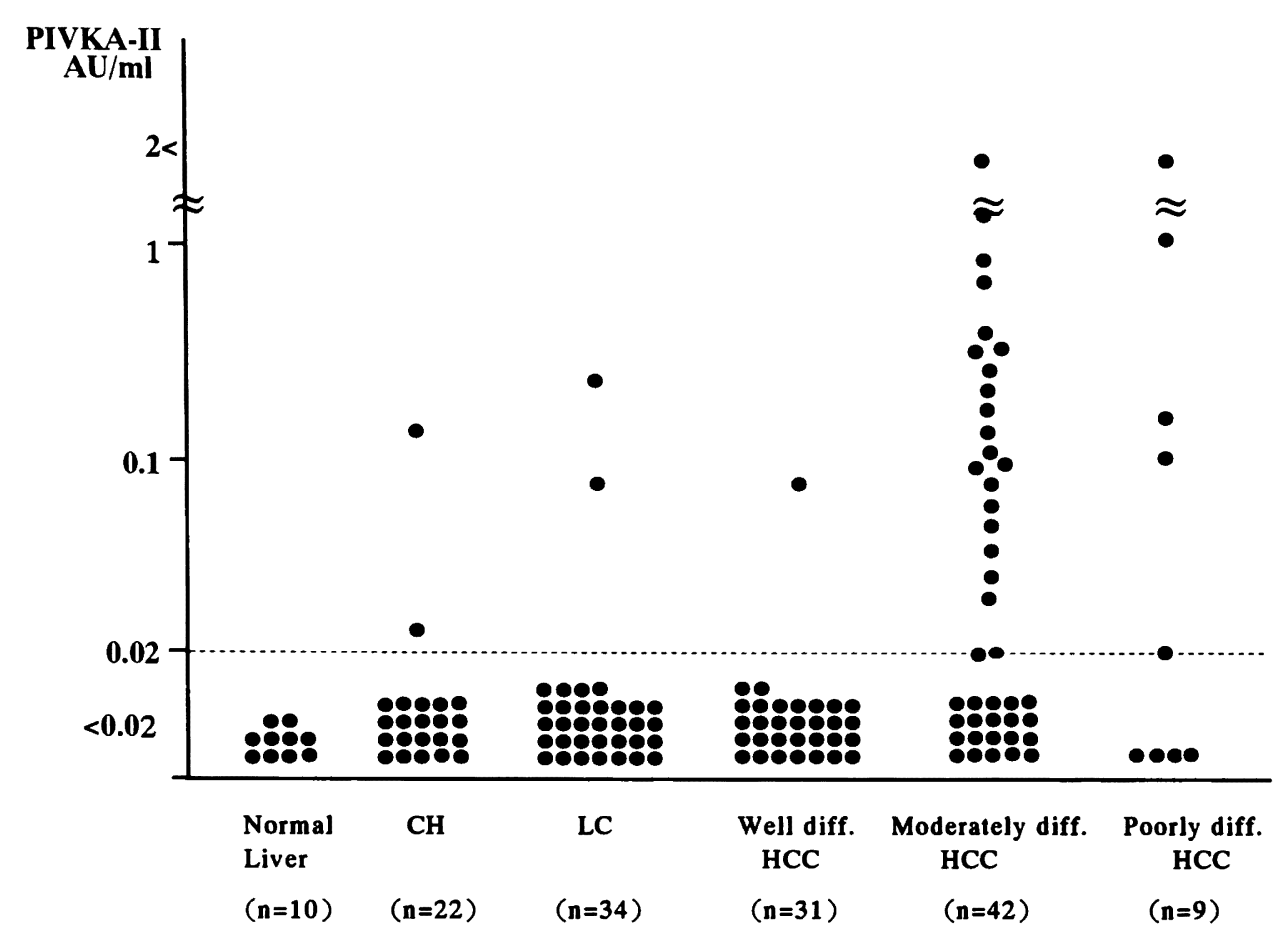

$\mathrm{CH}$ : chronic hepatitis, LC: liver cirrhosis, HCC: hepatocellular carcinoma, Well diff.: Well-differentiated, Moderately diff.: Moderately differentiated, Poorly diff.: Poorly differentiated.

Fig. 1 Serum concentrations of PIVKA-II in various liver diseases

Table 1 Positivity of PIVKA-II and AFP in small hepatocellular carcinomas according to tumor size

\begin{tabular}{cccc}
\hline & \multicolumn{3}{c}{ Positive rate } \\
\cline { 2 - 4 } $\begin{array}{c}\text { Tumor size } \\
(\mathrm{cm})\end{array}$ & PIVKA-II & AFP & $\begin{array}{c}\text { PIVKA-II } \\
\text { and/or AFP }\end{array}$ \\
\hline$\leqq 2.0$ & $21 \%(11 / 52)$ & $29 \%(15 / 52)$ & $38 \%(20 / 52)$ \\
$2.1 \sim 3.0$ & $57 \%(17 / 30)$ & $47 \%(14 / 30)$ & $80 \%(24 / 30)$ \\
Total & $34 \%(28 / 82)$ & $35 \%(29 / 82)$ & $54 \%(44 / 82)$ \\
\hline
\end{tabular}

Cut off : PIVKA-II $\geqq 0.02 \mathrm{AU} / \mathrm{m} l, \mathrm{AFP} \geqq 100 \mathrm{ng} / \mathrm{m} l$.

PIVKA-II 陽性率は34\%であった．また高感度PIVKAIIにおける特異度は $94 \%$ であった。一方, AFP の陽性 率は35\%で，またAFP と高感度 PIVKA-IIの同時測 定により陽性率は $54 \%$ まで上昇した (Table 1)。

肝細胞癌における高感度 PIVKA-II陽性率を腫瘍径 別に検討すると，2.1〜3.0cm では，57\%であったが， $2.0 \mathrm{~cm}$ 以下では，21\%に過ぎなかった。一方，AFP の 陽性率は2.1〜3.0cm では, 47\%であり, $2.0 \mathrm{~cm}$ 以下で は 29\%であった. また高感度 PIVKA-II と AFP の両 者いずれかの陽性率は 2.1 ～3.0cm では80\%であったが $2.0 \mathrm{~cm}$ 以下では $38 \%$ に過ぎなかった(Table 1).

2. 肝細胞癌における高感度 PIVKA-II と病理組織学 的所見との関係

肝細胞癌全体の分化度別の高感度 PIVKA-II 陽性率 
は，高分化型で $3 \%$ ああるのに対し，中分化型で $52 \%$, 低分化型では $56 \%$ であり，高分化型が中・低分化型と 比べて陽性率が極めて低かった (Fig. 1).

これまでの検討で高感度 PIVKA-II陽性例は中分化 型および低分化型が圧倒的であったので，さらに $2 \mathrm{~cm}$ 以下の症例について分化度別に検討した。高感度 PIVKA-IIは，高分化例において27例中1例，4\%に陽 性例を認め, 一方, 中・低分化例では25例中10例, $40 \%$ に陽性例を認めた. $2 \mathrm{~cm}$ 以下の症例においても 中・低分化例に陽性例が多い傾向は同様であった。

外科的切除された38例を対象に高感度 PIVKA-II陽 性16例, 陰性22例に分け, 組織学的進展所見について 検討した. 組織学的進展所見として被膜浸潤, 血管侵 襲の有無を検討した。被膜浸潤の頻度は陽性群でやや
高い傾向であったが，有意差は認めなかった，血管侵 襲の頻度は，高感度 PIVKA-II陽性で56\%，陰性例で 18\%であり，陽性群で有意に高頻度であった。一方， $\mathrm{AFP} 100 \mathrm{ng} / \mathrm{m} l$ を境に 2 群に分けて同様の検討をしたと ころ, 組織学的進展所見の有無には有意差は認めなかっ た (Table 2).

また，生存率および無再発生存率を検討した，高感 度 PIVKA-II陽性群と陰性群に分けて累積生存率を検 討すると， 5 年生存率はそれぞれ $62 \% ， 58 \%$ で，両群間 に有意差は認めなかった(Fig.2A)。しかし，無再発生 存率を検討すると PIVKA-II陽性群の方が陰性群より も有意に低率であった(Fig.2B)。一方，AFP100ng/ $\mathrm{m} l$ を境に 2 群に分けて同様の検討をしたところ, 予後 に有意差は認めなかった。

Table 2 Correlation between tumor markers and histologic findings in the patients who had undergone surgical resection

\begin{tabular}{|c|c|c|c|}
\hline & & fc-inf & $\mathrm{vp}$ \\
\hline High PIVKA-II group & $(n=16)$ & $44 \%(7 / 16)$ & $56 \%(9 / 16) \rightarrow \mathrm{P}<0$ \\
\hline Low PIVKA-II group & $(n=22)$ & $32 \%(7 / 22)$ & $18 \%(4 / 22)-$ \\
\hline High AFP group & $(n=15)$ & $53 \%(8 / 15)$ & $40 \%(6 / 15)$ \\
\hline Low AFP group & $(n=23)$ & $32 \%(6 / 23)$ & $30 \%(7 / 23)$ \\
\hline
\end{tabular}

High PIVKA-II group: PIVKA-II $\geqq 0.02 \mathrm{AU} / \mathrm{m} l$, Low PIVKA-II group : PIVKA-II $<0.02 \mathrm{AU} / \mathrm{m} l$, High AFP group: AFP $\geqq 100 \mathrm{ng} / \mathrm{m} l$, Low AFP group : AFP $<100 \mathrm{ng} / \mathrm{m} l$, fc-inf : infiltration to capsule, vp : vascular involvement

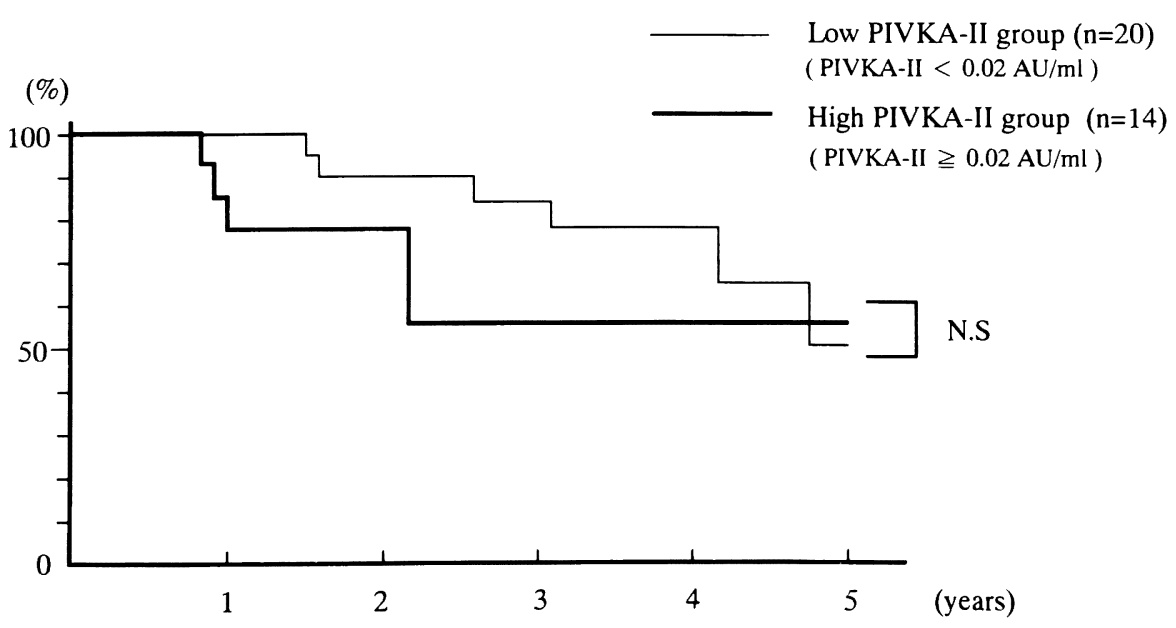

Fig. 2A Cumulative survival rates in the patients who had undergone surgical resection 
(\%)

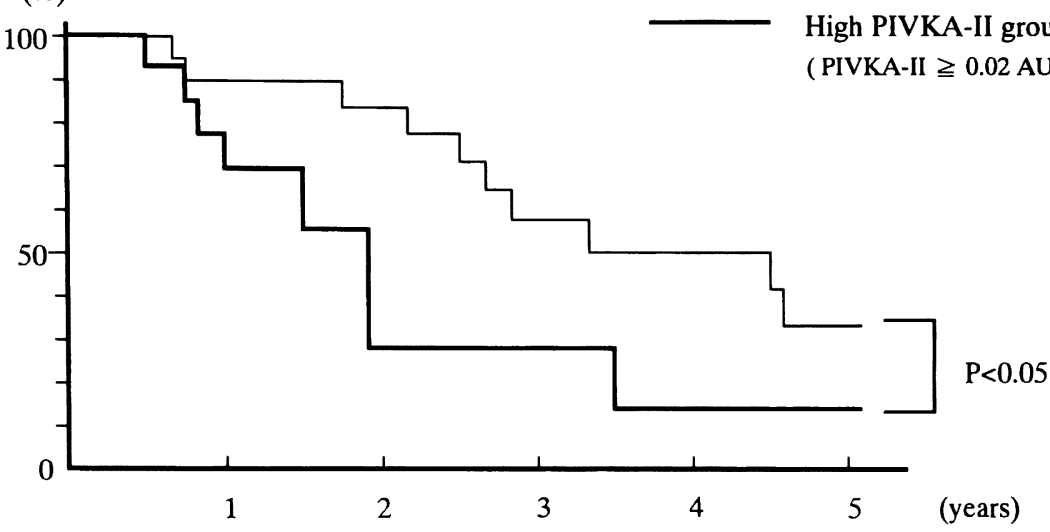

Low PIVKA-II group $(\mathrm{n}=\mathbf{2 0})$ (PIVKA-II $<0.02 \mathrm{AU} / \mathrm{ml}$ )

High PIVKA-II group $(n=14)$

PIVKA-II $\geqq 0.02 \mathrm{AU} / \mathrm{ml}$ )

Fig. 2B Non-recurrence survival rates in the patients who had undergone surgical resection

\section{考察}

肝細胞癌の腫瘍マーカーとしては AFP と PIVKA-II の有用性が広く知られている 性肝疾患での上昇例を経験することがあり，PIVKA-II は特異性は高いものの感度が低い点が問題であった。 しかし, AFP はフコシル化率の考案で特異性が増し7,8), PIVKA-II も高感度測定により感度が上昇したとの報 告がある ${ }^{9 \sim 11}$. しかし, 高感度 PIVKA-IIによる小肝

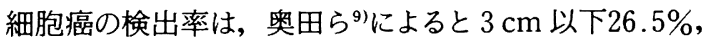
$2 \mathrm{~cm}$ 以下 $18.1 \%$, Kuromatsu㣙らによると $3 \mathrm{~cm}$ 以下 $26.8 \%, 2 \mathrm{~cm}$ 以下 $20.8 \%$ であり, 検出率は高くないの が現状である．今回の検討でも $3 \mathrm{~cm}$ 以下 $34 \%, 2 \mathrm{~cm}$ 以下 $21 \%$ と同様の結果であり, 小肝細胞癌における検 出には限界があると言わざるを得ない．さらに分化度 別にみると高分化型 $3 \%$, 中分化型 $52 \%$, 低分化型 $56 \%$ であり, 高分化型の検出率は非常に低かった．特に 2 $\mathrm{cm}$ 以下, 高分化型に限定すると 1 例 $4 \%$ のみで陽性で あった。斉藤ら ${ }^{12}$ の分化度別の報告も同様に高分化型で の検出率は低くなっていた。一般的に腫瘍径が小さい ほど高分化型の頻度が高く, 腫瘍が大きくなると中・ 低分化型が大部分を占めるようになることが知られて いる ${ }^{13)}$. 分化度別に検討した結果を合わせて考えると PIVKA-II 陽性率は中・低分化型をどれくらい含んで いるかによって決まるであろう。

従来から PIVKA-II陽性例は, 腫瘍径が大きく, 進 展例が多く，予後不良であるとの報告があるが2,14,15), 今回の検討でも中・低分化例がほとんどであった。さ
らに切除例において組織学的進展所見を検討すると， 血管侵襲の頻度は PIVKA-II 陽性例で有意に高頻度で あった。また PIVKA-II陽性例は, 無再発生存率が有 意に低率であり, 特に 2 年以内再発の頻度が高く, 転 移再発のポテンシャルが高いことを示唆していると思 われた．今回の検討により，小肝細胞癌においても PIVKA-II 陽性例はすでに進行癌である可能性が高く， 悪性度が高いことが示唆された。

以上のように小肝細胞癌における PIVKA-IIの検出 率には限界があるものの, 悪性度評価や予後予測に有 用性が認められた。

謝辞：稿を終えるにあたり，PIVKA-II測定をしていただ いた, 広島大学医学部附属病院中央検査部 米家泰子先生, 杉本好先生, 神辺真之先生に心より感謝申し上げます。

\section{文献}

1) Tanabe $Y$, Ohnishi $K$, Nomura $F$, et al : Plasma abnormal prothrombin levels in patients with small hepatocellular carcinoma. Am J Gastroenterol 83 : 1386-1389, 1988

2) Kasahara A, Hayashi N, Fusamoto $H$, et al : Clinical evaluation of plasma des- $\gamma$-carboxy prothrombin as a marker protein of hepatocel. lular carcinoma in patients with tumors of various sizes. Dig Dis Sci 38 :2170-2176, 1991

3) 中山泰一, 関 寿人, 城 知宏, 他: 肝細胞癌 (HCC)診断における高感度 PIVKA-II 測定法の 
有用性一従来法(エイテストモノ P-II) との比較 一. 肝臓 $34: 773-774,1993$

4) Nomura F, Ohnishi K, Tanabe $Y$, et al : Clinical features and prognosis of hepatocellular carcinoma with reference to serum alphafetoprotein levels. Cancer 64:1700-1707, 1989

5) Fujiyama S, Morishita T, Sagara K, et al : Clinical evaluation of plasma abnormal prothrombin(PIVKA-II) in patients with hepatocellular carcinoma. Hepatogastroentrology 33 : 201-205, 1986

6) Okuda H, Obata $H$, Nakanishi $T$, et al: Production of abnormal prothrombin (des- $\gamma^{-}$ carboxy prothrombin) by hepatocellular carcinoma. J Hepatol 4:357-363, 1987

7) Taketa K, Sekiya $C$, Namiki $M$, et al: Lectin-reactive profiles of alpha-fetoprotein characterizing hepatocellular carcinoma and related conditions. Gastroenterology 99 : 508518,1990

8) Aoyagi Y, Suzuki Y, Isemura M, et al : The fucosylation index of alpha-fetoprotein and its usefulness in the early diagnosis of hepatocellular carcinoma. Cancer 61:769-774, 1988

9）奥田博明, 中西敏巳, 斉藤明子, 他：肝細胞癌の
腫瘍マーカーとしての PIVKA-II および高感度 PIVKA-II. 肝胆膵 $34: 721-728,1997$

10) Kuromatsu R, Tanaka $M$, Shimauchi $M$, et al: Usefulness of ED 036 kit for measuring serum PIVKA-II levels in small hepatocellular carcinoma. J Gastroenterol 32: 507-512, 1997

11）斉藤 聡, 池田健次, 鯉田 䡎, 他：アビジン一 ビオチン法を用いた高感度 PIVKA-II測定による 肝細胞癌早期診断の試み. 肝藏 $34: 591-596$, 1993

12）斉藤 聡：高感度 PIVKA-II の臨床的有用性 (1) 一肝細胞癌早期診断を中心に一. 第43回日本臨床 病理学会インダストリアルセッション記録集：18 $-25,1996$

13）真島康雄, 藤本隆史, 岩井一郎, 他：新しいエ コー下細径針組織生検法による肝細胞癌の組織診 断とその意義. 肝臓 $29: 628-636,1988$

14) Suehiro $T$, Sugimachi $K$, Matsumata $T$, et al : Protein induced by vitamin $\mathrm{K}$ absence or antagonist II as a prognostic marker in hepatocellular carcinoma-comparison with alpha-fetoprotein. Cancer $73: 2464-2471$, 1994

15）板本敏行, 浅原利正, 片山幸治, 他：肝細胞癌切 除におけるPIVKA-II測定の意義. 日消外会誌 $24: 2721-2726,1991$ 


\section{Clinical evaluation of serum PIVKA-II in small hepatocellular carcinomas using a sensitive PIVKA-II assay}

Koji Kamada, Mikiya Kitamoto, Hiroshi Aikata, Yoshiiku Kawakami

Shoichi Takahashi, Waka Ohishi, Akiko Matsumoto, Keiko Shigemi

Hideki Takaishi, Hiroto Ishihara, Toshiyuki Ohbatake, Toshio NaKanishi ${ }^{1)}$

Toshiyuki Itamoto, Toshimasa Asahara ${ }^{2)}$ Fumio Shimamoto ${ }^{3)}$, Goro KajiYama ${ }^{1)}$

We measured the serum PIVKA-II levels in 82 patients with small hepatocellular carcinomas (HCC) using a sensitive PIVKA-II assay. The positive rate of PIVKA-II was $34 \%$ in patients with HCC less than $3.0 \mathrm{~cm}$ in diameter, while that was only $21 \%$ in those with $\mathrm{HCC}$ less than $2.0 \mathrm{~cm}$ in diameter. According to histological differentiation of HCC, the positive rate of PIVKA-II in patients with moderately and poorly differentiated $\mathrm{HCC}$ was $52 \%, 56 \%$, while that in those with well-differentiated $\mathrm{HCC}$ was $3 \%$, with significant difference $(\mathrm{P}<0.05)$. Frequency of vascular involvement was significantly greater in patients with positive PIVKA-II $(>0.02 \mathrm{AU} / \mathrm{ml})$ than in those with negative PIVKA-II, and non-recurrence survival rate was significantly lower in patients with positive PIVKA-II than in those with negative PIVKA-II $(\mathrm{P}<0.05)$.

${ }^{1}$ First Department of Internal Medicine, ${ }^{2}$ Second Department of Surgery, and ${ }^{3)}$ Department of Pathology, Hiroshima University School of Medicine(Hiroshima) 